\title{
DAKWAH KENABIAN DAN KONSTRUKSI \\ MASYARAKAT KHAYALAN
}

\author{
Ishak Hariyanto \\ Agus Dedi Putrawan \\ Fakultas Dakwah dan Ilmu Komunikasi UIN Mataram \\ e-mail: ishakharianto@yahoo.com \\ e-mail: agusdediputrawan@gmail.com
}

\begin{abstract}
The Prophet's missionary journey as an arena for building a humanitarian system that is mutually acceptable and recognizes the values of human equality in the social system is still a deviation, even though life must embrace one another, accept unconditionally and respect human values. Acceptance of fellow humans seems to have become a deviation and even becomes collective amnesia in social life. This collective amnesia is present in human life without realizing that we live in it so that acceptance in the name of the man as a form of hablumminannas is like the construction of a mere imaginary society. The construction of imaginary societies has occurred in Medina as a social institution on the journey of prophetic preaching. Such things occur as a process of living systems; a process of establishing his identity as a social system in building the ideal society that has ever existed on this earth. The Madinah community is a society based on a collective agreement stated in a charter, commonly known as the charter of Medina. Relations between groups are built based on the breath of acceptance among others, because of the awareness of the similarity of the nature and dignity of human beings. Why Medina is referred to as a normal social system identity, not because of the intersubjectivity; acceptability of humans and humans built from all components of the social system is always in communication and mutual action.
\end{abstract}

\section{Key Words:}

Collective Amnesia, Imaginary Society, Recognitive Learning 


\begin{abstract}
Abstrak
Perjalanan dakwah Nabi sebagai arena membangun sistem kemanusiaan yang saling berterima dan mengakui nilai-nilai kesamaan manusia dalam sistem sosial masih menjadi deviasi, padahal hidup harus saling merangkul, berterima tanpa syarat dan menghargai nilai-nilai kemanusiaan. Keberterimaan antar sesama manusia seolah-olah telah menjadi deviasi dan bahkan menjadi amnesia kolektif dalam kehidupan sosial. Amnesia kolektif ini hadir dalam hidup manusia tanpa disadari bahwa kita hidup di dalamnya sehingga keberterimaan atas nama manusia sebagai bentuk hablumminannas seperti konstruksi masyarakat khayalan semata. Konstruksi masyarakat khayalan pernah terjadi di Madinah sebagai institusi sosial dalam perjalanan dakwah kenabian. Hal demikian terjadi sebagai proses living system; suatu proses membangun identitas dirinya sebagai sistem sosial dalam membangun masyarakat ideal yang pernah eksis di muka bumi ini. Masyarakat Madinah adalah masyarakat yang berlandaskan kesepakatan bersama yang tercantum dalam sebuah piagam, yang biasa dikenal dengan piagam Madinah. Hubungan antar golongan dibangun berdasarkan nafas keberterimaan antar sesama, karena kesadaran akan adanya kesamaan hakikat dan martabat sebagai manusia. Kenapa Madinah disebut sebagai identitas sistem sosial normal, tak lain karena jalinan intersubjektivitas; keberterimaan manusia dengan manusia yang terbangun dari seluruh komponen sistem sosial selalu berada dalam komunikasi dan tindakan saling berterima.
\end{abstract}

\title{
Kata Kunci:
}

Amnesia Kolektif, Masyarakat Khayalan, Recognitive Learning 


\section{A. Pendahuluan}

Identitas atau organisasi sistem sosial manusia, sebagai the Ideal State of Social Order atau sebagai identitas sistem sosial normal adalah intersubyektivitas rekognitif. Intersubyektifitas rekognitif adalah relasi intersubyektivitas yang dibangun berdasarkan akan adanya keberterimaan antar sesama karena kesadaran akan adanya kesamaan hakikat dan martabat sebagai manusia. Ciri dari relasi intersubyektivitas ini adalah seluruh komponen sistem sosial selalu berada dalam komunikasi dan tindakan saling berterima sebagai nilai kesamaan spiritualitas manusia, yakni hubungan sesama manusia.

Keberterimaan atas nama manusia sebagai bentuk hablumminannas dalam tulisan ini tentu ingin melihat seperti apa masyarakat yang ideal yang pernah terjadi sebagai standar untuk mengukur nilai-nilai kerukunan dalam organisasi sistem sosial normal. ${ }^{1}$ Identitas sistem sosial normal yang berkaitan dengan posisi etika dan moralitas yang secara sahih bisa dilekatkan pada adanya keberterimaan moral yang bisa mengikat semua orang. Karena hari ini kita sudah tidak lagi dapat menemukan ada lingkungan yang ideal² sehingga bagaimana kita akan mampu membangun nilai-nilai kerukunan dalam diri manusia, namun kerukunan itu sendiri tidak pernah menyentuh tindakan kemanusiaan.

\footnotetext{
1 Penting untuk diketahui bersama bahwa ilmu-ilmu sosial kemanusiaan "cenderung kelihatan" kalah bersaing dengan ilmu-ilmu eksakta, disebabkan ketiadaan standarisasi kondisi normal atau ideal state sebagaimana yang dimiliki ilmu-ilmu kealaman.

2 Karena antara masyarakat normal dan tidak normal, "kelakuan baik dengan kelakuan buruk" kedua-duanya bercampur baur, menjadi rancu ketika tidak ada standar yang jelas, apa dan bagaimana masyarakat yang ideal itu.
} 
Seperti apa yang pernah dikatakan oleh Heiraklitus "semua yang ada di dunia ini akan berubah, tidak ada yang abadi, kecuali perubahan itu sendiri." ${ }^{3}$ Maka langkah pertama dalam pembahasan kali ini adalah "kita harus" menyepakati terlebih dahulu bagaimana masyarakat yang ideal itu atau The Ideal of Social Order. Yang berfungsi sebagai norma atau ukuran penilaian tentang normalitas pola prilaku empirik sosiologis, ${ }^{4}$ baru kemudian kita dapat mendiagnosa sistem kerukunan antar manusia yang rusak (anomie dan deviasi) dalam dunia empirik. Ideal dalam arti bahwa kita akan membayangkan bagaimana masyarakat yang kita idam-idamkan selama ini. Bagaimana predikat baik, jujur, kemurahan hati, kemaafan, kerukunan, dan kebijaksanaan yang melekat pada setiap individu atau dalam masyarakat itu sendiri.

Ideal yang dimaksud di sini adalah common sense berlaku di mana saja, seperti jujur, baik hati, bijaksana. Siapa yang tidak suka orang jujur, baik hati dan bijaksana. Siapa yang tidak suka masyarakat yang toleran, terbuka, tidak pernah konflik dan lain sebagainya, dan bahkan pembohong pun tidak suka dibohongi, mereka suka manusia yang jujur, penjahat tidak suka dijahati, penipu tidak suka ditipu, pencopet tidak suka dicopet.

Ideal dalam tulisan ini terlepas dari relativitas budaya atau marking dari suatu tempat yang mengideal-idealkan deviasi karena berada pada comfort zone (zona nyaman) seperti pulau khusus untuk para penjudi, sex bebas, yang memang

\footnotetext{
3 Poedjawijatna, Pembimbing ke Arah Alam Filsafat (Jakarta: PT. Pembangunan, 1980), 20.

${ }^{4}$ M. Husni Muadz, Anatomi Sistem Sosial Rekonstruksi Normalitas Relasi Intersubjektivitas dengan Pendekatan Sistem (Mataram: IPGH, 2014), 47.
} 
membius manusia agar nyaman di dalamnya. Ideal seperti di atas adalah yang common sense tanpa harus menimbulkan pertanyaan ikutan, diterima oleh akal sehat manusia dan secara kemanusiaan. Dalam pandangan ini, maksud dari masyarakat ideal adalah masyarakat yang alami. Masyarakat alami adalah masyarakat yang dibentuk atau didirkan di atas dasar yang alami, mengikuti hukum dan ketentuan alam, yang diturunkan ke alam ini dengan tidak sewanang-wanang, tidak kontradiktif, dan tidak berlawanan."

Masyarakat alami adalah masyarakat yang apa adanya, tidak dimanipulasi. Masyarakat dengan keberterimaan tanpa syarat, menjunjung tinggi rasa toleransi antar agama. Masyarakat alami adalah yang faham betul tugas, struktur dan fungsi masing-masing anggota masyarakat. Masyarakat alami mengambil keputusan sesuai kebenaran yang dapat dipertanggung jawabkan secara akal sehat "common sense" dan bukan berdasarkan suara terbanyak. Masyarakat alami bertindak berdasarkan kesadaran, karena "tindakan" harus dibedakan dengan "kejadian". Kejadian terjadi pada objek, bisa juga terjadi pada manusia sebagai subjek yang tidak memiliki kesadaran. ${ }^{6}$

Setelah kita sepakat akan adanya masyarakat ideal, penulis akan menunjukkan seperti apa konstruksi masyarakat khayalan yang ideal yang akan dianggap normal

\footnotetext{
${ }^{5}$ Muhammad al-Madani membedakan masyarakat alami dengan masyarakat buatan (masyarakat industrial). "sebuah masyarakat yang dibangun atas dasar penentangan terhadap hal-hal yang bersifat alami dan penolakan terhadap ketentuan-ketentuan penciptaanya, atau di dalamnya ditemukan hukum-hukum pergaulan dan prilaku masyarakat yang menentang dan mengalahkannya, maka masyarakat tersebut dinamakan masyarakat industri." lihat. Muhammad Al Madani, Masyarakat Ideal dalam Persfektif Surah An-Nisaa (Jakarta: Pustaka Azzam, 2002), 62-63.

${ }^{6}$ Kejadian bisa dicari penyebabnya di luar manusia, sebab kejadian bisa merupakan kejadian mekanik (dilahirkan oleh unsur-unsur fisik) atau kejadian biologis (yang dapat dijelaskan dengan hukum kausalitas).
} 
(pernah terjadi) dan bagaimana yang dianggap menyimpang. Terlebih dahulu kita akan masuk pada pembahasan pertama tentang masyarakat ideal atau masyarakat yang kita konstruk sendiri "sesuai kesepakatan" yang tentu berlaku di semua tempat atau minimal sebagian besar tempat (untuk tidak mengatakan seluruhnya) yang tidak perlu dipertanyakan lagi (common sanse).

\section{B. Konstuksi Masyarakat Khayalan}

Terminologi pertama adalah gambaran tentang "Masyarakat Madani". Masyarakat madani dapat dikatakan masyarakat ideal yang diimpi-impikan dalam kehidupan sosial masyarakat selama ini. ${ }^{7}$ Orang yang pertama kali mengusung istilah masyarakat Madani adalah Anwar Ibrahim, mantan Wakil Perdana Menteri Malaysia. Menurutnya, masyarakat Madani merupakan sistem sosial yang subur berdasarkan prinsip moral yang menjamin keseimbangan antara kebebasan individu dengan kestabilan masyarakat. Inisiatif individu dan masyarakat berupa pemikiran, seni, pelaksanaan pemerintah yang berdasarkan undang-undang, dan bukan nafsu atau keinginan individu. Menurutnya pula, masyarakat Madani mempunyai ciricirinya yang khas: kemajemukan budaya (multicultural), hubungan timbal balik (reprocity), dan sikap saling menghargai. Masyarakat Madani adalah masyarakat yang selalu memelihara prilaku yang beradab, sopan santun berbudaya tinggi, baik dalam menghadapi sasama manusia, atau alam lainnya. Bahwa karakter masyarakat Madani ini merupakan "guiding ideas", meminjam istilah Malik Bennabi,

\footnotetext{
${ }^{7}$ Karena masyarakat madani masih dalam upaya dan perjuangan untuk mewujudkannya, maka atas dasar inilah penulis menganggapnya sebagai masyarakat ideal yang diimpi-impikan.
} 
dalam melaksanakan ide-ide yang mendasari masyarakat Madani, yaitu prinsip moral, keadilan, kesamaan, musyawarah dan demokrasi." 8

Masyarakat Madani adalah masyarakat yang selalu memelihara perilaku yang beradab, sopan santun, berbudaya tinggi, dan ramah dalam menghadapi lingkungannya. Masyarakat yang hubungan antara warganya sangat harmoni, saling menghargai kepentingan masing-masing. Menyadari bahwa dalam berinteraksi antar sesama manusia walaupun masing-masing mempunyai hak asasi, tetapi haknya itu dibatasi oleh hak yang dimiliki orang lain dalam kapasitas yang sama, mereka menyadari dalam berinteraksi akan lahir hak dan kewajiban. Semakin sering berinteraksi semakin banyak hak dan kewajiban terlahir. Masyarakat Madani menggambarkan setiap individu dalam sebuah masyarakat ketika berinteraksi menjunjung tinggi nilai moral dan etika baik yang berkaitan dengan hak asasi manusia universal maupun etika dan moral ideologi dan kebudayaan setempat. Masyarakat Madani mencerminkan masyarakat yang saling peduli satu sama lain, menghargai setiap perbedaan, tidak mudah percaya propaganda-propaganda media yang berpotensi memecah belah semangat solidaritas. Sudah jelas gambaran tentang masyarakat madani yang begitu ideal, jika setiap masyarakat baik berbangsa maupun bernegara menerapkan seperti itu maka aman, damai, makmur dan sejahteralah suatu negara. Namun konsep tentang masyarakat madani hanya sebatas bayang-bayang belaka. Di dalam kehidupan sosial kekinian kita belum pernah melihat masyarakat yang se-ideal masyarakat madani.

\footnotetext{
8 Ubaedillah dkk, Demokrasi Hak Asasi Manusia dan Masyarakat Madani (Jakarta: ICCE UIN Jakarta, 2000), 193.
} 
Di era globalisasi saat ini, di mana individu-individu dicetak menjadi warga kampung global yang hedonis, pragmatis dan realis yang berpotensi mengikis rasa saling menghargai, mengikis kearifan lokal, keberterimaan antar sesama. Globalisasi cenderung menciptakan budaya merunduk (tidak memperdulikan lingkungan karena sibuk dengan media sosial) yang biasa dikenal dengan telekomuniti. ${ }^{9}$ Masyarakat Madani adalah sebuah masyarakat yang dicita-citakan setiap individu berbangsa dan bernegara.

\section{Masyarakat Normal Yang Pernah Terjadi}

\section{a. Masyarakat Madinah}

Kenapa harus Madinah? Bila kita kembali ke masa Rasullullah SAW di Madinah, sungguh pasti kita akan terkejut. ${ }^{10}$ Sebab kita akan disuguhkan dengan sebuah masyarakat ideal yang pernah eksis di muka bumi ini. Bentuk masyarakat yang kini tidak kita temukan kembali di era kontemporer saat ini. Masyarakat Madinah adalah masyarakat yang berlandaskan kesepakatan bersama yang tertulis dalam sebuah Piagam, yang biasa dikenal dengan piagam Madinah, ditulis di atas kepentingan segala golongan, sehingga mampu menjadi

\footnotetext{
${ }^{9}$ Komunitas baru yang terlahir akibat dari kebutuhan akan informasi setiap detik, yang dibawa oleh internet. Dalam arti masyarakat media (computer mediated sommunication) akan melahirkan komunitas baru (Facebook, Twitter, Whatsup, BBM, Line, dan lain-lain), yang menafikan keberadaan komunitas nyata. Setiap orang membawa serta komunitas baru mereka ke dalam komunitas nyata. Dalam sebuah perkuliahan di suatu kelas, di mana terdapat sekumpulan mahasiswa yang sedang menggelar presentasi, namun karena dosen mereka sedang pergi ke toilet, mereka membuka facebook untuk terhubung dengan komunitas (telekomuniti) mereka di luar kelas (komunitas di dalam komunitas).

10 "Pada abad pertengahan, kita akan terkaget-kaget melihat perbedaan besar antara kedua dunia (Islam dan Barat). Anda akan tercengang melihat sebuah dunia yang penuh dengan kehidupan, kekuatan dan peradaban, yakni dunia Islam, dan sebuah dunia lain yang primitif, sama sekali tidak ada kesan kehidupan, ilmu pengetahuan dan peradaban yakni dunia Barat." Lihat, Mustafa As-Siba'I" Peradaban Islam" (Versi Digital Edisi Baru, September 2011, www.referensimuslim.com).
} 
titik balik peradaban secara radikal untuk merombak secara total nilai, simbol, dan struktur masyarakat yang telah akut sebelumnya. Masyarakat Madinah adalah masyarakat yang menghasilkan dari suatu tatanan masyarakat yang benar-benar baru.

Madinah menjadi sebuah identitas masyarakat yang normal. Menjadi percontohan tatkala dibandingkan dengan wilayah-wilayah tetangganya waktu itu. Hubungan antar golongan dibangun berdasarkan nafas keberterimaan antar sesama, karena kesadaran akan adanya kesamaan hakikat dan martabat sebagai manusia. Kenapa Madinah disebut sebagai identitas sistem sosial normal, tak lain karena jalinan intersubjektivitas (keberterimaan manusia dengan manusia) yang terbangun dari seluruh komponen sistem sosial selalu berada dalam komunikasi dan tindakan saling berterima.

Dalam tulisan ini bukan semata-mata ingin menyodorkan nomalisasi masyarakat madinah, karena kita selalu terjebak pada apa yang menjadi hasil. Kenapa masyarakat madinah disebut masyarakat normal yang ideal pada zaman sekarang. Ada suatu hal yang harus kita ungkap kenapa masyarakat madinah demikian. Orang-orang pada masyarakat madinah diberikan predikat-predikat dengan orang-orang jujur, amanah, tablik, fatanah, berterimaan, baik, benar, menyayangi, mengasihi, mencintai, suka menolong dan lain sebagainya. Yang harus kita ketahui adalah predikat adalah hasil, masyarakat madinah normal ideal adalah predikat, orang-orangnya jujur adalah predikat, ia datang belakangan setelah suatu hal yang diterapkan di sana. Apa itu? inilah yang disebut dengan pembelajaran rekognitif. 


\section{b. Masyarakat Madinah Dilihat Sebagai Sebuah Sistem}

Sebuah sistem adalah sesuatu yang memelihara keberadaannya dan berfungsi sebagai sebuah kesatuan melalui interaksi antar bagiannya. ${ }^{11}$ Sifat dasar sistem adalah sifat keseluruhan yang justru tidak ditemukan dalam bagian-bagiannya. Jika melihat masyarakat sebagai sebuah sistem, maka yang harus kita lakukan pertama kali adalah memecah bagian-bagian dari sebuah sistem menjadi unsur-unsur terkecil, lalu mengamati sifat, ciri dan prilaku bagian-bagian tersebut. Tindakan selanjutnya adalah merekonstruksi terhadap sifat atau ciri keseluruhan berdasarkan sifat bagian-bagian. ${ }^{12}$

Sebagaimana sudah dipaparkan di atas, masyarakat madinah sebagai sebuah identitas sistem sosial normal selalu dalam relasi intersubyektivitas. Mereka mengada dalam interaksi komunikasi antar Bani-Bani di Madinah. Dengan bertemu, berinteraksi maka output adalah sebuah keniscayaan. Hasil dari kebertemuan akan dilihat sebagai sebuah side effect dari setiap interaksi antar individu maupun kelompok komunitas. Perdamainan dan kesejahteraan Madinah jangan dilihat sebagai sebuah inti, namun seyogyanya dilihat sebagai sebuah output emergent properties dari tindakan setiap komponen, bertemu, berinteraksi, berdialog, menulis perjanjian, menyepakati dengan keberterimaan, memandang tanpa tendensi siapa, tujuan, manfaat tapi keberterimaan atas dasar manusia subjek-subjek.

\footnotetext{
${ }^{11}$ M. Husni Muadz, Diksusi dalam pengantar berpikir sistem dan hukum sistem sekolah 2017.

12 M. Husni Muadz, Anatomi Sistem Sosial, 54.
} 
Di Madinah waktu itu bercirikan masyarakat yang majemuk, terdapat berbagai macam golongan; Quraisy, Bani 'Aus, Banu Sa'idah, Banu Al-Hars, Banu Jusyam, Banu An-Naijar, Banu 'Amr bin 'Awf, Banu Al-Nabit, Banu Al'Aws, Yatsrib dan Bani Khazraj. Ada berbagai macam agama berdiam di sana (Yahudi, Kristen, Pagan dan Islam). Kaum Ansor adalah kaum yang lahir dan tinggal di Madinah terlebih dahulu sebelum nabi dan para sahabat hijrah dari Mekkah ke Madinah. Mereka kaum Ansor sangat baik, berpegang teguh pada janji, gagah berani melawan kezaliman, dermawan dan perduli atas sesama manusia. Meskipun di Madinah terdapat berbagai agama; Yahudi, Kristen, Pagan dan Islam tidak nampak persaingan radikal seperti yang kita lihat di Mekkah.

Kaum Muhajirin (quraisy) terdiri dari para sahabat yang sejak di Makkah ikut bersama nabi memperjuangkan agama tauhid, terdapat sahabat-sahabat dengan predikat keutamaan individu masing-masing seperti Abubakar as siddiq, Umar, Utsman, Ali dan lain-lain. Mereka terkenal dermawan, baik hati, jujur, teguh terhadap janji, tidak pernah putus asa, ikut menemani nabi hijrah ke Madinah. Sebagian besar sahabat ketika di mekkah adalah seorang saudagar kaya raya, pembisnis yang sukses, pembesar suku. Setelah masuk Islam, mereka mengorbankan harta mereka demi dakwah Nabi SAW untuk tegaknya agama Islam agama perdamaian. Selain mengorbankan harta jiwa dan raga mereka serahkan sepenuhnya untuk berdakwah di Mekkah dan Madinah waktu itu. 


\section{c. Struktur Fungsional Masyarakat Madinah}

Setiap elemen masyarakat baik individu maupun kelompok bahumembahu, berinteraksi atas dasar keberterimaan. Ikatan persaudaran dari hasil interaksi antar komponen, bekerjasama atas dasar keberterimaan antar subjek meniadakan intoleransi. Perbedaan di antara mereka diyakini merupakan sebuah anugerah dari tuhan untuk memantik kesadaran moral saling melengkapi satu dengan lainnya. Interaksi melahirkan komitmen dan komitmen melahirkan tindakan yang dapat kita lihat sebagai sebuah emergent. Dari aturan yang tertulis berupa piagam madinah, dapat kita lihat pembagian tugas dan fungsi masing-masing elemen masyarakat:

"Kaum muhajirin dari Quraisy, Banu Auf, Banu Sa'idah, Banu Al-Hars, Banu Jusyam, Banu An-Naijar, Banu 'Amr bin 'Awf, Banu Al-Nabit dan Banu Al'Aws sesuai keadaan kebiasaan mereka bahu membahu membayar diat di antara mereka dan mereka membayar tebusan tawanan dengan cara baik dan adil di antara mukminin." 13

"Orang-orang mukmin yang taqwa harus menentang orang yang diantara mereka mencari atau menuntut sesuatu secara zalim, jahat, melakukan permusuhan atau kerusakan di kalangan mukminin. Kekuatan mereka bersatu dalam menentangnya, sekalipun ia anak dari salah seorang di antara mereka. ${ }^{14}$ Seorang mukmin tidak boleh membunuh orang beriman lainnya lantaran membunuh orang kafir. Tidak boleh pula orang beriman membantu orang kafir untuk membunuh orang beriman. ${ }^{15}$ Jaminan Allah satu. Jaminan perlindungan diberikan oleh mereka yang dekat. Sesungguhnya mukminin itu saling membantu, tidak bergantung kepada golongan lain." 16

"Sesungguhnya orang Yahudi yang mengikuti kita berhak atas pertolongan dan santunan, sepanjang mukminin tidak terzalimi dan ditentang olehnya. ${ }^{17}$

\footnotetext{
13 Piagam Madinah pasal 2-10.

14 Piagam Madinah pasal 13

15 Piagam Madinah pasal 14

16 Piagam Madinah pasal 15

${ }^{17}$ Piagam Madinah pasal 16
} 
Perdamaian mukminin adalah satu. Seorang mukmin tidak boleh membuat perdamaian tanpa ikut serta mukmin lainnya di dalam suatu peperangan di jalan Allah, kecuali atas dasar kesamaan dan keadilan di antara mereka." 18

Yang jarang kita perhatikan dan ambil manfaatnya dari pembelajaran masyarakat Madinah adalah interaksi dan keberterimaan subjek antar subjek. Kita cenderung dan selalu saja melihat hasil. Hasil adalah sebuah keniscayaan ketika interaksi itu terjalin terus menerus. Interaksi yang terjalin intens atas dasar keberterimaan subjek antar subjek dalam keutuhan selalu melahirkan kebaharuan. Inilah yang ingin digambarkan dalam tulisan ini.

\section{d. Rekonstruksi Sistem Masyarakat Madinah}

Terciptanya masyarakat Madinah yang ideal bukan sesuatu hal yang sudah jadi, namun penuh dengan proses-proses yang dibangun dengan keberterimaan antar sesama karena kesadaran akan adanya kesamaan hakikat dan martabat sebagai manusia. ${ }^{19}$ Ini menjadi prasyarat yang menjadi stimulus terciptanya masyarakat ideal tersebut. Sebagaimana kita ketahui di Madinah, orang muslim ketika itu merupakan orang yang berpandangan positif dan terbuka, inklusif terhadap berbagai kebudayaan bangsa lain. Kelebihan inilah yang menjadikannya menjadi yang pertama kali mampu menyatukan khazanah

\footnotetext{
18 Piagam Madinah pasal 17

${ }^{19}$ Diceritakan, pada suatu musim Haji, Muhammad saw. berdakwah kepada jamaah Yasrib dan disambut dengan positif. Mereka berjanji akan datang lagi di musim Haji berikutnya dan meminta Muhammad saw. mengirimkan salah seorang sahabatnya untuk mengajarkan Islam kepada penduduk Yasrib. Muhammad saw. mengutus Mus'ab bin Umair sebagai duta Islam dan ia cukup berhasil dalam menjalankan misinya. Pada tahun berikutnya, penduduk Yatsib datang dengan jumlah yang lebih banyak. dan berikrar janji setia kepada Muhammad saw. dan memintanya untuk pindah ke Yatsrib. Mereka bersedia membela Muhammad saw. dan sahabat-sahabatnya dengan jiwa dan harta mereka. Dikutip dari, Muhammad Syafi'i Antonio, Muhammad the Super Leader Super Manager (Jakarta: Tazkia Publishing \& ProLM Center, 2009), 148.
} 
bersama secara kosmopolit dan internasional. Kaum muslim selain menyebarkan pesan-pesan kebaikan (common sense), ternyata mereka pandai bertindak dan juga selalu rajin belajar secara praksis.

Pasca diterimanya kaum Muhajirin (warga pendatang) oleh kaum Ansor (warga pribumi) Pada 622 M, Nabi Muhammad saw. membangun masyarakat yang kita sebut ideal. Kaum Ansor menerima dengan senang hati, mereka dipersaudarakan satu dengan lainnya. Setiap anggota warga Madinah merasa aman dengan menjunjung nilai-nilai keadilan, prinsip kesetaraan, penegakan hukum, jaminan kesejahteraan bagi semua warga serta perlindungan terhadap minoritas (piagam madinah). Sikap keberterimaan antar sesama terjalin, hubungan antar masyarakat tanpa syarat (tanpa membeda-bedakan pendatang dan pribumi). Oleh sebab itu para cendikiawan muslim menganggap masyarakat Madinah-lah Prototype masyarakat ideal yang bisa disandingkan dengan masyarakat ideal dalam konsep Civil Society. ${ }^{20}$

Di Madinah setiap warga merasa damai, saling berterima dalam hidup bermasyarakat. Mereka selalu berkonsultasi kepada Nabi, apa dan bagaimana hidup beragama dan bermasyarakat. Masyarakat Madinah mencerminkan masyarakat dengan kepatuhan, kemaafan, sabar, berterima antar sesama, dermawan dan lain-lain, dengan membentuk sebuah komunitas yang Islami dengan tatanan sosial yang lebih baik. Tentunya masyarakat muslim awal membutuhkan suatu daerah yang mampu memberikan perlindungan bagi mereka sekaligus tempat untuk membentuk kawasan percontohan komunitas

\footnotetext{
$20 \mathrm{lbid}, 147$.
} 
muslim ideal. ${ }^{21} \mathrm{Nabi}$ di Madinah berhasil merekonstruksi komunitas dengan tipetipe orang yang sesuai dengan moralitas tinggi walaupun pada waktu itu tidak ada sekolah-sekolah atau pendidikan formal seperti universitas.

Mengadakan kontrak sosial antara penduduk Madinah yang menjadi sarat keberterimaan perbedaan agama, lalu membangun sebuah arena pertemuan Nabi dan para sahabatnya dalam mendiskusikan sesuatu dan mempersatukan kaum Ansor dan Muhaiirin berupa masjid yang tidak hanya berfungsi sebagai tempat beribadah semata. Rasulullah meletakkan asas-asas masyarakat Islam yang kemudian hal ini mampu melahirkan sebuah peradaban baru di dunia. Asas asas tersebut antara lain al-lkha' (persaudaraan), al-Musa'wah (persamaan), al-Tasa'muh (toleransi), al-Ta'awun (tolong menolong) dan al'Adalah (keadilan). ${ }^{22}$

Menyadari bahwa madinah adalah plural, maka Konstitusi Madinah secara tersurat adalah sebuah keniscayaan yang berisikan ketentuan yang bertautan dengan demokrasi politik. Konstitusi Madinah merupakan hasil dari bertemu, berdialog dalam keterbukaan dan berkomitmen setiap komponen masyarakat di Madinah, tanpa adanya kebertemuan, berdialog dengan hantaran bahasa, serta keterbukaan semua orang, niscaya adanya sebuah consensus untuk membentuk masyarakat yang aman dan damai. Dalam pembukaan konstitusi Madinah yang berbunyi:

\footnotetext{
21 lbid, 148.

22 lbid, 21.
} 


\begin{abstract}
“Dengan Asma Allah yang Maha Pengasih dan Maha Penyayang. Ini adalah kitab (ketentuan tertulis) dari Nabi Muhammad saw. antara orang-orang Mukmin yang berasal dari Quraisy dan Yatsrib dan yang mengikuti mereka, kemudian menggabungkan diri dengan mereka dan berjuang bersama mereka. "Dalam pembukaan ini terdapat lima pokok kandungan antara lain 1), Penempatan asma Allah swt. pada posisi teratas. 2), Perjanjian masyarakat (social contract) secara tertulis. 3), kemajemukan masyarakat yang ikut dalam Konstitusi Madinah. 4), keanggotaan terbuka (open membership) dan 5), Persatuan dalam ke-bhineka-an (unity in diversity). Para ahli Ilmu pengetahuan, khususnya ahli sejarah menyebut naskah politik yang dibuat Nabi Muhammad saw. itu dengan nama yang macam-macam. W. Montgommery Watt menyebutnya dengan "The Constitution of Medina", RA.Nicholson "Charter", Maiid Khadduri "Treaty", Philip K. Hitti "Agreement", Zainal Abidin Ahmad "Piagam" ${ }^{3}$
\end{abstract}

Piagam Madinah disusun sejelas-jelasnya untuk meredam gesekan-gesekan

sengit Bani 'Aus dan Bani Khazraj di Madinah. Piagam Madinah menetapkan sejumlah hak dan kewajiban bagi kaum Muslim, kaum Yahudi, dan komunitaskomunitas piagam di Madinah, yang pada akhirnya membentuk mereka menjadi suatu kesatuan komunitas yang dalam bahasa Arab disebut Ummah. Setiap komponen bahu-membahu bekerjasama untuk menjujung tinggi perjanjian tertulis (piagam madinah) untuk menjamin suatu perdamaian dan kesejahteraan.

\footnotetext{
23 Lihat Muhammad Alim, Demokrasi dan Hak Asasi Manusia dalam Konstitusi Madinah dan UUD 1945 (Yogyakarta: UII Press, 2001), 3, 52. Lihat juga, Ana Bilqis Fajarwati, Islam dan Demokrasi, Membaca Pemikiran Fatima Mernissi (Jurnal Religio Volume 03 Nomor 01 Tahun 2013), 60 - 78. Pasal 45, Apabila mereka (pendukung piagam) diajak berdamai dan mereka (pihak lawan) memenuhi perdamaian serta melaksanakan perdamaian itu, maka perdamaian itu harus dipatuhi. Jika mereka diajak berdamai seperti itu, kaum mukminin wajib memenuhi ajakan dan melaksanakan perdamaian itu, kecuali terhadap orang yang menyerang agama. Setiap orang wajib melaksanakan (kewajiban) masing-masing sesuai tugasnya. Pasal 46, Kaum Yahudi Al-'Aws, sekutu dan diri mereka memiliki hak dan kewajiban seperti kelompok lain pendukung piagam ini, dengan perlakuan yang baik dan penuh dari semua pendukung piagam ini. Sesungguhnya kebaikan (kesetiaan) itu berbeda dari kejahatan (pengkhianatan). Setiap orang bertanggung jawab atas perbuatannya. Sesungguhnya Allah paling membenarkan dan memandang baik isi piagam ini. Pasal 47, Sesungguhnya piagam ini tidak membela orang zalim dan khianat. Orang yang keluar (bepergian) aman, dan orang berada di Madinah aman, kecuali orang yang zalim dan khianat. Allah adalah penjamin orang yang berbuat baik dan takwa. dan Muhammad Rasulullah saw.
} 


\section{Intersubjektivitas Rekognitif}

Sebelum lebih jauh membahas tentang recognitive learning, terlebih dahulu penulis ingin menjabarkan apa pengertian recognitive learning ini secara singkat. Kata rekognitif ini berasal dari bahasa Inggris yakni recognition yang berarti pengakuan atau penghargaan. Akan tetapi dalam bahasa Indonesia recognition ini diterjemahkan menjadi rekognitif. Dan kata rekognitif dalam konteks pembelajaran diartikan menjadi suatu konsep pembelajaran yang berbasiskan kemanusiaan dalam membangun hubungan antar sesama tanpa syarat (intersubyektifitas), bagaimana menjadi damai, saling berterima dalam hidup bermasyarakat. Hubungan berterima tersebut merupakan nilai-nilai yang harus ada dalam pembelajaran rekognitif. Tidak hanya itu, rekognitif juga adalah pembelajaran yang mengedepankan nilai-nilai moral seperti perilaku baik, kepatuhan, kemaafan, sabar, berterima satu sama lain, dermawan dan lain-lain. Di samping itu juga, pembelajaran rekognitif adalah suatu konsep pembelajaran non-material, dan selalu menyaratkan komunikasi verbal dan non verbal diantara semua makhluk untuk terus menjalin komunikasi dengan efektif. Dikatakan efektif karena ada perubahan diantara semua sistem sehingga untuk mewujudkan tujuan di atas maka nilai-nilai rekognitif atau perilaku-perilaku baik harus menjadi basis dalam setiap pembelajaran. ${ }^{24}$

Mengapa pembelajaran rekognitif harus mengedepankan nilai-nilai di atas, karena fakta yang terjadi sekarang adalah secara kognisi masyarakat memahami nilai-nilai kebaikan tersebut, bahkan sumbernya sekalipun. Pendakwah atau

\footnotetext{
24 Husni Muadz, Draf Buku Anatomi Sistem Sosial (Mataram: IPGH, 2015), 1. Tulisan ini juga bisa dilacak dalam buku Anatomi Sistem Sosial Rekonstruksi Normalitas Relasi Intersubyektivitas Dengan Pendekatan Sistem (Mataram: Institut Pembelajaran Gelar Hidup IPGH, 2014)
} 
masyarakat tahu akan nilai-nilai kebaikan tersebut, apa yang dilarang, pandai berbicara tentang konsep nilai-nilai kebaikan. Akan tetapi terjadi ketidak seimbangan antara pemahaman dan perilaku karena dakwah selama ini baru menyentuh ranah kognisi saja, sehingga tak perlu di pungkiri lagi output dari dakwah sekarang ini adalah orang-orang yang pintar tapi bukan orang-orang baik. Dalam pembelajaran ini juga medium yang menarik untuk dikaji adalah bahasa, karena dakwah juga dilakukan dengan jalan bahasa tindakan, maka bahasa dalam pembelajaran rekognitif menjadi hal yang sangat urgen. Keurgenan tersebut karena bahasa merupakan makhluk yang sangat unik dan bahkan manusia tidak bisa lepas darinya. Manusia tidak bisa hidup tanpa bahasa, karena bahasa adalah alat pemersatu, dan bahkan alat pemisah dan sekaligus sebagai alat untuk membangun hubungan dengan siapapun.

Prinsip pembelajaran rekognitif selalu menjaga kelangsungan sistem, pola-pola interaksi antar komponen menggunakan mekanisme autopoitik (identitas yang memiliki kemampuan memperbaiki diri jika terjadi kerusakan pada komponen). Institusi sosial selalu dalam proses menjadi seperti living system (suatu proses membangun identitas dirinya sebagai sistem sosial). Dengan kata lain institusi sosial masih berada dalam proses perjuangan membangun indentitas kolektif mereka menjadi sebuah sistem, atau secara ontologis institusi sosial hari ini lebih cocok disebut sebagai institusi pembelajaran. Oleh karena itu, pembelajaran utama yang berkaitan dengan pembelajaran di atas adalah pembelajaran membangun organisasi relasi yang membentuk keutuhan sistem sosial. Inilah yang disebut $M$. Husni Muadz dengan sebutan "Pembelajaran Rekognitif" pembelajaran yang 
dilakukan sepanjang hayat. Pembelajaran rekognitif adalah pembelajaran intersubjektivitas atau pembelajaran membangun hubungan antar sesama manusia atas dasar keberterimaan tanpa syarat. Jika dilihat dalam institusi pembelajaran di masyarakat ini akan kita temukan dua jenis pembelajaran. Pertama pembelajaran primer yang bersifat rekognitif, Kedua pembelajaran derivatif yang bersifat kognitif.

Pembelajaran primer adalah pembelajaran yang berhubungan dengan bagaimana membangun keberterimaan dengan sesama manusia. Jenis pembelajaran primer ini berkaitan dengan pembelajaran yang memungkinkan semua komponen bisa hidup saling berterima, pembelajaran tipe ini sepenuhnya barsifat non-material. Pembelajaran derivatif berkaitan dengan usaha memahami dan memanfaatkan alam secara umum. pembelajaran derivatif diperlukan untuk kesempurnaan sistem sosial, sedangkan pembelajaran rekognitif diperlukan demi konstitusi sistem sosial yang memiliki ciri atau identitas keutuhan yang khas, yaitu semua berada dalam dialog dan saling berterima. konsekuensinya adalah pembelajaran primer (pembelajaran emosional) dan pembelajaran skunder (terkait dengan pemahaman akan sesuatu) adalah sama-sama penting. Pembelajaran etika bisa didekati dengan dua caya yaitu kognitif (knowing that) dan rekognitif (knowing how).

Institusi pembelajaran rekognitif ini berbicara institusi yang memungkinkan manusia menjadi baik dan bisa hidup saling berterima dengan manusia lainnya. Ketika terjadi benturan-benturan dan konflik mereka dengan mudah bisa saling memaafkan. Untuk mewujudkan pembelajaran rekognitif minimal dua keadaan. Pertama, harus ada dalam ranah relasional, setting-nya bersifat langsung dan relasi 
intersubjektivitas. Kedua, pembelajaran ini berada dalam setting alami, yang memberikan akses bagi siapa saja dan keberadaan mereka adalah sebuah keniscayaan, maka pembelajaran ini pun menjadi sebuah keniscayaan. Berkaitan dengan konsep di atas, berikut penulis akan bercerita bagaimana komunitas kesadaran, ${ }^{25}$ komunitas yang berupaya memangkas generasi atas dasar masalah bersama (patologi yang akut). Dalam pembahasan ini penulis akan menceritakan sebuah komunitas bertemu, berdialog dan berkomitmen yang mampu melahirkan identitas sistem sosial manusia yang unik. Pola-pola interaksi yang terjadi memungkinkan masing-masing orang selalu berada dalam dialog dan dalam tindakan saling berterima. ${ }^{26}$ Inilah yang sebenarnya disebut dengan kondisi masyarakat normal dan bahkan masyarakat ideal yang kita bayang-bayangkan dalam ranah kognitif selama ini. Apa konsepnya? Bagaimana penerapannya? kapan dan di mana institusinya?

"Kegiatan ini berawal dari hasil diskusi setiap malam Sabtu di kediaman Husni Muadz, P. hd. Sebagai penggagas konsep keilmuan dan ditindak lanjuti oleh Sahabudin dan Ustadz Sairi sebagai tokoh masyarakat untuk mengaplikasikan hasil diskusi setiap malam sabtu tersebut di Dusun Bangket Bilong Lombok. Di tempat lain juga dibentuk komunitas ini, seperti di Bodak Bagu ada ustadz Zaenuri, di Karang Genteng ada Zuhairi, di BTN BHP ada Ibu Ema". ${ }^{27}$

${ }^{25}$ Karena pembelajaran ini ada di sekitar kita, namun tidak banyak yang menyadari akan kehadiran pembelajaran ini, maka komunitas kesadaran di Bangket Bilong mencoba managemen pembelajaran rekognitif ini dan hasil-nya dapat kita baca dalam gambaran-gambaran selanjutnya.

26 "pola-pola interaksi inilah yang selalu dikonservasi yang membuatnya menjadi sistem yang khas. karena mengada dalam dialog dan tindakan saling berterima adalah identitas sistem sosial manusia, maka semua institusi sosial yang ada, mulai dari keluarga, sekolah, rumah sakit, sampai dengan perusahaan dan bahkan Negara, harus memiliki identitas yang sama, karena semua institusi ini adalah bagian dari sistem sosial manusia." M. Husni Muadz, Anatomi Sistem Sosial, 200.

27 Ustaz Sairi wawancara Oktober 2015. 
Pembelajaran ini dikenal dengan pembelajaran rekognitif atau pembelajaran primer. Pembelajaran primer berkaitan dengan bagaimana menerapkan nilai kebenaran dalam ranah tindakan. Pembelajaran primer berlangsung dalam institusi komunikasi atau dialog.

"Pembelajaran primer berikaitan dengan pembelajaran yang langsung di ranah relasional atau ranah intersubjektivitas (bukan ranah kognitif semata). Misalnya; bila kita ingin menjadi pemaaf, tidak cukup hanya dengan mengetahui seluk beluk kemaafan, seperti pentingnya apa, apa dasar-dasar logisnya, dan seterusnya. menjadi pemaaf kita harus belajar langsung ketika kita berhubungan dengan orang lain, yaitu belajar memberi maaf ketika kemaafan itu justru diperlukan (misalnya; di saat ada konflik) dan kalau tidak maka akan terjadi bentuk hubungan yang semakin jauh, tegang dan melelahkan." ${ }^{28}$

Dalam upayanya mengaplikasikan pembelajaran primer di masyarakat khususnya komunitas kesadaran di Bangket Bilong (Lombok). Maka seyogyanya dibuat formulasi-formulasi seperti; pembekalan, kapan dan bagaimana memulainya, lalu siapa saja yang akan terlibat. Triono Soendoro mengungkapkan:

\begin{abstract}
"Menciptakan tim yang benar-benar hidup (living systems), menyatu, berinteraksi satu dengan yang lain, dan bekerja sama sesama anggota tim untuk mencapai tujuan bersama memerlukan praktek yang dilakukan bersama-sama dan terus menerus tanpa henti. Merekalah yang harus aktif dalam menentukan wujud organisasi yang didambakan bersama (shared vision) agar dapat diwujudkan suatu ikatan yang saling mengenal dan mencirikan komunitas praktik yang benar-benar nyata. Ciri-ciri komunitas praktik adalah kesepakatan antar anggotanya, usaha bersama, dan kesamaan rangkaian rutinitas, aturan, prilaku yang tersirat serta pengetahuan yang mengiringi anggota tim itu sendiri." 29
\end{abstract}

\footnotetext{
${ }^{28}$ M. Husni Muadz, Anatomi Sistem Sosial, 17.

${ }^{29}$ Sebuah sambutan Triono Soendoro, dalam M. Husni Muadz, Anatomi Sistem Sosial, xi.
} 


\section{E. Penutup}

Dakwah yang dijalankan Nabi semata-mata dalam membangun sistem kemanusiaan yang saling berterima dan mengakui nilai-nilai kemanusiaan. Akan tetapi ajaran-ajaran tersebut telah luput dan menjadi amnesia kolektif. Amnesia ini hadir dalam hidup manusia tanpa disadari bahwa kita hidup di dalamnya sehingga keberterimaan atas nama manusia sebagai bentuk hablumminannas seperti konstruksi masyarakat khayalan semata. Perjalanan dakwah yang dilakukan Nabi Muhammad seolah-olah menjadi konstruksi masyarakat khayalan semata. Akan tetapi hal tersebut pernah terjadi sebagai proses living system (suatu proses membangun identitas dirinya sebagai sistem sosial dalam membangun masyarakat ideal yang pernah eksis di muka bumi ini). Yakni masyarakat Madinah yang masyarakatnya selalu membangun konsensus bersama yang tercantum dalam sebuah piagam, yang biasa dikenal dengan piagam Madinah, ditulis di atas kepentingan segala golongan, sehingga mampu menjadi titik balik peradaban secara radikal untuk merombak secara total nilai, simbol, dan struktur masyarakat yang telah akut sebelumnya.

Seperti apa yang pernah terjadi di Madinah ketika perjalanan dakwah kenabian, tentu banyak pelajaran berharga yang harus kita ambil dan kita terapkan. Konsep pembelajaran rekognitif hadir sebagai konstruksi masyarakat khayalan yang diterapkan di Lombok. Konsep ini ditawarkan sebagai konsep yang sederhana namun sangatlah prinsipil yakni bagaimana bertemu, dengan hantaran bahasa, berdialog, kemudian berkomitmen/mengikat janji dan nantinya akan melahirkan tindakan (sebagai konsekuensi moral). Penerapannya sekarang dan kini, serta 
institusinya di mana ada interaksi dengan sesama manusia di situ dimulai pembelajarannya. 


\section{Daftar Pustaka}

Alim, Muhammad, Demokrasi dan Hak Asasi Manusia dalam Konstitusi Madinah dan UUD 1945. Yogyakarta: UII Press, 2001

Al Madani, Muhammad, Masyarakat Ideal dalam Persfektif Surah An-Nisaa. Jakarta: Pustaka Azzam, 2002

As-Siba'l, Mustafa, "Peradaban Islam", Versi Digital Edisi Baru, September 2011, www.referensimuslim.com.

Bilqis Ana, Fajarwati, "Islam dan Demokrasi, Membaca Pemikiran Fatima Mernissi". Jurnal Religio Volume 03 Nomor 01 Tahun 2013

Husni M. Husni, Anatomi Sistem Sosial Rekonstruksi Normalitas Relasi Intersubjektivitas dengan Pendekatan Sistem. Mataram: IPGH, 2014

Poedjawijatna, Pembimbing ke Arah Alam Filsafat. Jakarta: PT. Pembangunan, 1980

Syafi'i, Antonio, Muhammad, Muhammad the Super Leader Super Manager. Jakarta: Tazkia Publishing \& ProLM Center, 2009

Ubaedillah dkk, Demokrasi Hak Asasi Manusia dan Masyarakat Madani. Jakarta: ICCE UIN Jakarta, 2000 


\section{Petunjuk Penulisan}

Tasâmuh menerima tulisan dalam bentuk artikel dan laporan penelitian, baik yang menggunakan bahasa Indonesia, Inggris, maupun Arab, dengan ketentuan sebagai berikut:

1. Tulisan tersebut belum pernah diterbitkan atau dipublikasikan dalam suatu jurnal berkala atau buku.

2. Topik tulisan berkisar pada kajian-kajian yang berkaitan dengan ilmu dakwah dan Komunikasi.

3. Judul tulisan maksimal 14 kata.

4. Semua tulisan harus menyertakan abstrak (100-150 kata) dan kata kunci (3-7 kata).

5. Jumlah halaman antara 15-20 nomor halaman dengan ukuran kwarto spasi ganda dengan menggunakan jenis huruf Futura $\mathrm{Lt} \mathrm{B} \dagger$ dan besar hurup 12 pt.

6. Setiap kata Arab yang belum resmi terbakukan dalam bahasa Indonesia ditulis mengikuti pedoman transliterasi yang ditetapkan dan cara penulisannya dimiringkan (italic), hal ini juga berlaku untuk kata-kata asing yang lain (seperti bahasa Inggris dan bahasa Daerah) dan cara penulisannya dimiringkan (italic),

7. Transliterasi tidak berlaku untuk nama orang, tempat, institusi, dan sejenisnya.

8. Penulis menyerahkan file beserta print out naskahnya.

9. Semua tulisan menggunakan referensi model footnote dengan teknik penulisan sebagai berikut: Nama Penulis, Judul Buku Yang Ditulis Miring (Kota Penerbit: Nama Penerbit, Tahun Terbit), Nomor Halaman. Sebagai contoh:

a. Buku atau Kitab:

- John Lewis Coser, The Function of Social Conflict (New York: Free Press, 1969), 125. 
- Sofian Effendi, Membangun Martabat Manusia Dalam Perspektif Islam (Yogakarta: UGM Press, 2005), 24.

- Ibnu Jarir al-Thabari, Jami' al-Bayan, Jilid 9 (Beirut: Dar alKutub Ilmiyah, 1992), 67.

b. Buku Terjemahan:

David Hill, Pengembangan dan Pemberdayaan Masyarakat, ter. Adam Hulaimi, Jilid 2 (Jakarta: Pustaka Pelajar, 1997), 127.

c. Artikel dalam Buku atau Ensiklopedi:

- Nurcholis Majid, "Cendekiawan dan Penguatan Civil Society di Indonesia" dalam Peran Cendekiawan Muslim Dalam Menegakkan Hak Politik Civil Society, ed. Tim Editor Masika (Jogjakarta: Bintang Budaya, 1996), 124.

- D.S. Adam, "Theology," Encyclopedia of Religion and Ethics, ed. James Hastings, Jilid 4 (New York: Charles Scribner's Sons, tt), 293.

d. Artikel dalam Jurnal:

Faisal Ismail, "On Developing Liberation Theology in Islam," dalam Jurnal Gazwatul Fikri, Vol. 9 No. 2 (Yogyakarta: Fakultas Dakwah UIN Sunan Kalijaga, Desember 1999), 165.

e. Artikel dalam Media Massa:

Fawaizul Umam, "Quo Vadis Kebebasan Beragama di Indonesia", dalam Koran KOMPAS, Edisi 30 Maret 2001, 4.

f. Kitab Suci:

QS. al-Qashash (28): 5. Perjanjian Baru, Yoh ( 20): 31.

g. Bila mengutip ulang referensi yang sama secara berurut, maka cukup tulis: Ibid. Jika halamannya berbeda, cukup tambahkan nomor halamannya: Ibid., 14.

h. Bila referensi terkutip ulang berselang oleh satu atau lebih referensi berbeda, maka cukup tulis last name pengarang berikut satu kata awal judul dari referensi dimaksud. Misalnya, Zahrah, Ushûl..., 35. 
10. Selain mencantumkan footnote, penulis juga harus mencantumkan DAFTAR PUSTAKA dengan aturan penulisan diurutkan secara alfabetis. Nama penulis diketik dengan mendahulukan nama marga atau nama akhir jika nama penulis terdiri dari 2 kata atau lebih, judul buku atau nama jurnal maupun nama media massa ditulis miring (Kota Penerbit: Lembaga Penerbit, Tahun Terbit) tanpa diakhiri tanda titik.

Contoh:

a. Buku: Nasution, Harun, Perkembangan Pemikiran Cendikiawan Muslim Indonesia (Jakarta: Dunia Ilmu, 1998)

b. Jurnal: Ismail, Faisal, "On Developing Liberation Theology in Islam," dalam Jurnal Gazwatul Fikri, Vol. 9 No.2 (Yogyakarta: Fakultas Dakwah UIN Sunan Kalijaga, Desember 1999)

c. Media massa: Umam, Fawaizul, "Quo Vadis Kebebasan Beragama di Indonesia", dalam Koran KOMPAS, Edisi 30 Maret 2001

d. Makalah: Akbar, Muhammad, "Membangun Paradigma Baru Fakultas Dakwah", dalam Makalah Seminar Pengembangan Fakultas Dakwah di Indonesia, Mataram, 3 Maret 2004 